\title{
Early programming of hypertension
}

\author{
Adriana Iturzaeta ${ }^{(1 D}$, María M. Sáenz Tejeirab (D)
}

\begin{abstract}
Hypertension (HTN) is a modifiable risk factor for cardiovascular disease (CVD) and should be included in the study of developmental origins of health and disease (DOHaD).

During intrauterine and perinatal development, different environmental factors have an impact on the early programming of noncommunicable diseases (NCDs).

This review provides a summary of the evidence that connects the fetus' plasticity and adaptive changes to unfavorable environmental factors that alter the adult phenotype in the development of HTN. Such adaptive changes result from epigenetic changes that favor the development of HTN and CVD in adulthood with intergenerational implications. Lastly, we mention preventive strategies to limit or reverse any variable that may alter developmental programming leading to HTN later in life.

Key words: blood pressure, hypertension, fetal programming, DOHaD, epigenetics. https://decs.bvsalud.org/es/

http: / / dx.doi.org/10.5546/aap.2022.eng.e8
\end{abstract}

To cite: Iturzaeta A, Sáenz Tejeira MM. Early programming of hypertension. Arch Argent Pediatr 2022;120(1):e8-e16.

and Disease,

Sociedad Argentina

de Pediatría

(DOHaD-SAP).

b. Hospital Italiano

de Buenos Aires,

Autonomous

City of Buenos

Aires, Argentina;

Hospital General

de Agudos Dr.

Juan A. Fernández,

Autonomous

City of Buenos

Aires, Argentina.

Committee on

Cardiology, Sociedad

Argentina de

Pediatría.

E-mail address:

Adriana Iturzaeta:

aiturzaeta@yahoo.com.ar

Funding:

None.

Conflict of interest: None.

Received: 3-17-2021

Accepted: 7-21-2021

\section{INTRODUCTION}

Hypertension (HTN) is a major modifiable risk factor for the development of cardiovascular disease (CVD) in adults and originates during childhood; its prevalence is estimated at $3.5-5 \%$ in pediatrics. ${ }^{1-5}$

Given the large impact of adult CVD in public health, strategies have been proposed to identify risk factors to reduce the population's morbidity and mortality. ${ }^{3-5}$

In this regard, the introduction of the concept of developmental origins of health and disease $(\mathrm{DOHaD})$ assigns the alteration of normal development before conception, during intrauterine and perinatal life, and the first years of life a critical role as a triggering factor of noncommunicable diseases (NCDs). Certain environmental factors and an adverse maternal environment during gestation and perinatal life may affect developmental plasticity, during which the fetus adapts to environmental conditions that pose a future risk for HTN and CVD in adulthood, as well as other metabolic, neurodevelopmental, and immune diseases. ${ }^{3-5}$

The evidence also demonstrated that the effects of programming in the case of parental exposure to environmental challenges may be transmitted from one generation to the next. ${ }^{5}$

Therefore, it is important to know and detect the effects of adverse environmental conditions on fetal and perinatal development, epigenetic mechanisms, and other adaptive responses that may be key in the early programming of HTN in future life, and assess strategies aimed at reducing the risk. ${ }^{5}$

\section{ENVIRONMENTAL IMPACT ON THE DEVELOPMENT OF HTN}

Recent epidemiological studies have demonstrated that the stages prior to conception and the fetal and perinatal periods may contribute to the development of HTN and other risk factors for CVD in the future (Table 1). . $^{3,46-10}$

This hypothesis, initially proposed by Barker, states that a low birth weight (LBW) induced by gestational malnutrition produce certain adaptations in the fetus that predispose or "program" the development of HTN and CVD later in life, a process known as "fetal programming," which then originated the concept of DOHaD. ${ }^{10,11}$

LBW, prematurity, and intrauterine growth restriction (IUGR) usually result from developmental plasticity to adverse factors, including 
nutrient deficiency, either due to an inadequate maternal diet -as demonstrated in studies about the offspring of populations that suffered from hunger during gestation- or placental insufficiency. ${ }^{3,4,9,12,13}$

There is evidence that indicates an association between LBW, prematurity, the effect of a rapid postnatal growth in infants with a LBW (Helsinki cohort and Nord-Trøndelag Study), and changes in body mass index (BMI) during childhood and the risk for HTN later in life. ${ }^{3,4,13-18}$

Another study agreed that a history of preterm birth was the event most commonly associated with blood pressure (PA) during adulthood. It reported a significant increase of $4.2 \mathrm{mmHg}$ in systolic BP, an increase of $2.6 \mathrm{mmHg}$ in diastolic BP, an increase of $3.1 \mathrm{mmHg}$ in 24-hour ambulatory systolic BP, and a greater risk among women. ${ }^{19}$

According to the evidence, there are critical periods during fetal development (organogenesis) and the early postnatal period which are considered the most sensitive ones to nutritional deficiency and a risk for future development of HTN. ${ }^{13,20}$

It is important to note that both LBW and excessive fetal growth (macrosomia) predispose subjects to a higher risk for CVD in adulthood. This is the case of children born to mothers with a high BMI or diabetes. Maternal metabolic status, pre-gestational obesity, and excessive weight gain during pregnancy may be implied in a transgenerational vicious cycle of early programming of $\mathrm{BP} .{ }^{21}$

Cohort studies in humans showed that both gestational HTN and early-onset preeclampsia were associated with the development of HTN in their offspring, especially during the neonatal period, which demonstrates the role of placental insufficiency in the programming of BP. ${ }^{22}$

In addition, other causes of fetal stress also result in inadequate fetal growth and correlate to

TABLE 1. Adverse environmental factors and developmental origins of health and disease ${ }^{6}$

\begin{tabular}{|c|c|c|c|}
\hline $\begin{array}{l}\text { Stage of } \\
\text { development }\end{array}$ & $\begin{array}{l}\text { Type of } \\
\text { exposure }\end{array}$ & $\begin{array}{c}\text { Effects in experimental } \\
\text { models }\end{array}$ & $\begin{array}{l}\text { Observations } \\
\text { in humans }\end{array}$ \\
\hline Preimplantation & $\begin{array}{l}\text { - Malnutrition or } \\
\text { low protein diet }\end{array}$ & - Blast cells deficiency & \\
\hline Placental & $\begin{array}{l}\text { - Placental insufficiency } \\
\text { - Multiple pregnancy }\end{array}$ & $\begin{array}{l}\text { - Models of placental } \\
\text { insufficiency associated } \\
\text { with IUGR }\end{array}$ & $\begin{array}{l}\text { - Placenta size in correlation } \\
\text { with birth weight and future } \\
\text { cardiovascular conditions } \\
\text { in initial Barker's studies }\end{array}$ \\
\hline \multirow[t]{2}{*}{ Intrauterine } & $\begin{array}{l}\text { - Hormones (folate, } \\
\text { glucocorticoids) } \\
\text { - Methylated compounds }\end{array}$ & $\begin{array}{l}\text { - Impaired glucose tolerance test, } \\
\text { diabetes mellitus, } \\
\text { reduced } \beta \text {-cell mass } \\
\text { - Obesity, impaired nephrogenesis }\end{array}$ & $\begin{array}{l}\text { - Impaired glucose tolerance test, } \\
\text { diabetes mellitus, reduced } \beta \text {-cell mass } \\
\text { - Obesity, impaired nephrogenesis }\end{array}$ \\
\hline & $\begin{array}{l}\text { - Protein-calorie malnutrition } \\
\text { - Hyperglycemia } \\
\text { - Glucocorticoid excess } \\
\text { - Altered renin-angiotensin } \\
\text { system } \\
\text { - Inflammation } \\
\text { - Free fatty acids }\end{array}$ & $\begin{array}{l}\text { - Increased expression of } \\
\text { angiotensin II type } 1 \text { receptor } \\
\text { - Cardiorenal abnormalities } \\
\text { - Structural vascular changes } \\
\text { - Hypertension }\end{array}$ & $\begin{array}{l}\text { - Low nephron number } \\
\text { - Structural vascular changes } \\
\text { - Hypertension }\end{array}$ \\
\hline Perinatal & $\begin{array}{l}\text { - Malnutrition } \\
\text { - Overnutrition } \\
\text { - Toxic substances } \\
\text { - Hypoxia } \\
\text { - Oxidative stress } \\
\text { - Metal deficiency }\end{array}$ & $\begin{array}{l}\text { - Epigenetic changes } \\
\text { - Future cardiorenal syndrome } \\
\text { - Future metabolic syndrome }\end{array}$ & $\begin{array}{l}\text { - Future CVD } \\
\text { - Future metabolic syndrome }\end{array}$ \\
\hline
\end{tabular}

IUGR: intrauterine growth restriction, CVD: cardiovascular disease. 
a higher prevalence of HTN during adolescence and adulthood. As an example, it is worth noting hypoxia; maternal stress (environmental, emotional, and physiological); microbiota changes; early exposure to glucocorticoids; exposure to toxic substances, such as nicotine and tobacco smoke; alcohol use; and maternal sleep deprivation. ${ }^{23-36}$

Changes in microbiota may affect BP by regulating sensitivity to salt. Early exposure to high glucocorticoid levels alters placental autoregulation of $11 \beta$-hydroxysteroid dehydrogenase type 2 , which has a lower activity in males, increasing cortisol levels in fetal circulation. Such adaptation may be associated with IUGR, altered nephrogenesis, high BP, changes in fat metabolism, insulin resistance, and variations in the hypothalamic-pituitaryadrenal axis during adolescence and adulthood. Exposure to toxic substances, such as a mother who smokes (nicotine), or tobacco smoke causes vasoconstriction and a reduced placental blood flow, with impaired vascular development and a lower kidney size and increased BP during early childhood. Fetal exposure to alcohol and cocaine may also affect multiple organs and potentially increase the risk for organ dysfunction and disease during adulthood. Sleep restriction during pregnancy may increase the BMI and $\mathrm{BP}$ levels of the offspring due to alterations in glucose metabolism, inflammatory pathways, and a predisposition to preterm birth, with more marked effects in female children. In animal models, sleep restriction may increase BP due to changes in kidney development. ${ }^{23-36}$

\section{ADAPTATIONS IN PROGRAMMING OF HTN}

As a result of an interaction between the genome and an unfavorable intrauterine environment, the fetus produces structural and functional responses that, in the short term, become adaptive and promote survival chances; however, in the long term, they may have adverse consequences. Changes in cardiovascular, renal, and autonomic nervous system development have been suggested to be related to BP regulation. ${ }^{5,37}$

\section{Renal alterations}

The renal phenotypes that have been reported in developmental programming of HTN include small kidney size at birth with a reduced nephron number (if the adverse effect occurs during the period of greatest nephrogenic plasticity, before 34 weeks of gestation); alterations in renal function, sodium transport, renin-angiotensinaldosterone system (RAAS), and sympathetic renal nerves that regulate renal function. ${ }^{5}$

Maternal factors, such as nutrient restriction that limits nephron endowment couple with agerelated nephron loss, have been associated with HTN programming in adulthood. ${ }^{38}$

Brenner and Chertow suggest that the risk for essential HTN during adulthood increases as a result of an impaired renal development implied in IUGR. This hypothesis is supported by studies in humans that demonstrate that a lower nephron number in subjects with LBW, with a smaller glomerular filtration area, causes compensatory glomerular hyperfiltration and, eventually, glomerular hypertrophy, kidney injury (microalbuminuria, proteinuria), and glomerulosclerosis, and favors the development of HTN. ${ }^{38-41}$

Other observations suggest a direct relationship between birth weight and nephron number, a reverse association between birth weight and HTN in adulthood, and a reverse association between nephron number and BP, regardless of whether the number of nephrons reduces congenitally or in the postnatal period..$^{40,41}$

The developmental programming of HTN demonstrated that the glomerular filtration rate reduces after protein-calorie dietary restriction during pregnancy, as well as with the administration of glucocorticoids, alcohol, and maternal diabetes. ${ }^{5}$

Programmed HTN models showed tubulointerstitial injury and alterations in the pathways that regulate fibrosis, inflammation, oxidative stress, and changes in gene and / or protein expression in sodium, calcium, and water channels that may affect tubular function and sodium homeostasis. ${ }^{5}$

In experimental animal models, the hypothesis proposed was that the early changes in the kidney cortex microenvironment alter sodium management, resulting in an increased sensitivity to salt. In some preterm or LBW infants, BP values are increased with an excessive sodium intake due to alterations in related regulation mechanisms, either due to a smaller glomerular filtration area associated with a reduction in nephron number or a higher 
sodium tubular reabsorption. ${ }^{4,5,42,43}$

There is little information about renal nerves and their potential role in programmed HTN, although sympathetic innervation plays a major role in BP regulation and sodium transport. ${ }^{44}$

\section{Cardiovascular alterations}

Cardiovascular structural and functional alterations may significantly contribute to HTN and are present in programmed HTN models., ${ }^{3,4,5,45}$

The cardiac phenotype typically presents a reduced number of cardiomyocytes and/or increased cardiac hypertrophy in the offspring following maternal protein restriction, vitamin $\mathrm{D}$ deficiency, and restriction of placental function in experimental models of fetal programming associated with LBW. Cardiac hypertrophy was also observed in male offspring and systolic and diastolic dysfunction in male and female offspring for 3 months in the case of a fat-rich diet during gestation in animals. $3,4,46-50$

Children with a history of fetal stress and LBW showed a more reduced endothelium-dependent vasodilation, regardless of current BMI. ${ }^{51}$ These data indicate that children with a LBW develop endothelial dysfunction. ${ }^{52}$

Experimental studies support the possibility that fetal stress may affect vasculogenesis and cause endothelial dysfunction and vascular remodeling. Such phenotypic and functional changes in vascular smooth muscle cells arise in response to vasoconstriction and vasodilation mediators secreted by endothelial cells. This process is characterized by changes in vascular structure, such as an alteration in wall thickness and lumen diameter (with a major role played by metalloproteinases) and changes in vascular mechanical properties, which may develop or be precursors of HTN over life. ${ }^{5,50-54}$

In the case of IUGR, it was suggested that elastin synthesis is altered during the fetal stage, a period of rapid vascular growth, which may lead to changes in vascular mechanics, reduced arterial elasticity, and development of HTN in the long term. ${ }^{55}$

This hypothesis is supported by the association between LBW and arterial rigidity observed in preterm infants when high pulse wave velocity was measured, a clinical indication of accelerated vascular aging. ${ }^{56-57}$

\section{Autonomic nervous system alterations}

There is strong evidence that the increase in sympathetic nervous system activity contributes to the pathogenesis of essential HTN and that it may originate since the beginning of development through sodium reabsorption in renal tubules. Such sympathetic hyperactivity may be a common underlying mechanism of HTN induced by maternal obesity. ${ }^{3,4,5,58}$

In addition, bidirectional interactions occur between the sympathetic nervous system and the immune system. Particularly, the relationship between $\mathrm{T}$ cell adaptive immunity and the enteric nervous system, which increases, through microbiota composition, proinflammatory cytokines and alters intestinal permeability by intervening in the programming of salt-sensitive HTN. ${ }^{54,59,60}$

\section{MECHANISMS CONTRIBUTING TO HTN PROGRAMMING}

The organ system alterations mentioned above may be associated with varying changes in mediators. The most relevant ones are the RAAS, the epigenetic modulation of certain genes (especially those related to the insulin-like growth factor [IGF]), and reactive oxygen species (ROS). ${ }^{5}$

All RAAS components were affected by developmental programming of HTN in several models, including the administration of glucocorticoids, a diet rich in fat, sodium, sucrose, fructose and low in proteins, which may account for the alterations in renal and vascular function. . $1-64^{-6}$

The findings common to these models suggest that a maternal diet with protein restriction leads to a perinatal suppression of the intrarenal RAAS and a subsequent impairment of nephrogenesis and reduced nephron number, and predisposes to HTN in adulthood. In addition, differences have been reported between males and females in BP programming during nephrogenesis. ${ }^{7,63,65}$

The epigenetic modifications in the beginning of the embryonic stage account for changes in gene expression and regulate their function, but without altering the DNA sequence. Such changes may be transmitted to future generations. ${ }^{5,66}$

Such epigenetic mechanisms entail DNA methylation (the most studied mechanism in models of developmental programming of HTN), histone modification, control of gene expression by non-coding RNA, and chromatin formation. ${ }^{5,67}$ 
Experimental studies in humans and animals suggest that epigenetic changes are one of the mechanisms responsible for fetal programming that may explain both organ system alterations and vascular dysfunction and HTN in the offspring. These epigenetic changes consist in modifications in genes related to the RAAS, angiotensin type 1 receptor, vascular tone, ion channels, epithelial sodium channels, $\mathrm{Na}^{+}-\mathrm{K}^{+}-2 \mathrm{Cl}^{-}$cotransporter, an increased expression of micro-RNA that regulates the translation of angiotensinconverting enzyme-1, micro-RNA associated with cardiac injury, angiogenesis, and cell changes, modifications in endothelial nitric oxide synthase (eNOS), and HSD11B2 hypermethylation, among others (Table 2). 3,4,68-70

Studies in humans who suffered calorie and nutrient restriction during the intrauterine period showed modifications in IGF gene methylation and in genes involved in cardiovascular function and inflammation..$^{71,72}$

It is also worth noting that DNA methylation occurring in cytosine-phosphate-guanine sites is mediated by enzymes that depend on adequate micronutrient levels, such as choline, niacin, folic acid, vitamins B6 and B12, vitamin C, methionine, glutathione, zinc, selenium, and retinoic acid. Such micronutrient deficiency may cause the fetus to suffer lower tissue oxygenation, increased oxidative stress, activation of apoptosis due to mitochondrial dysfunction, and alteration in organ development and may predispose to metabolic syndrome and HTN in adulthood. ${ }^{31,54,73,74}$
The paternal environment, in case of calorie restriction before and during puberty, also plays a role in the programming of metabolic and cardiovascular disorders. ${ }^{75}$

Another major contribution of molecular biology that should be taken into consideration, and that is related to the fetal origin of NCDs, is telomere shortening. Telomeres are made up of repeated segments of DNA at the end of chromosomes and their main function is to confer structural stability and regulate the life of cell lines. Telomere shortening, in the case of adverse events during the intrauterine period, is associated with the development of chronic, cardiovascular, and metabolic diseases and a shorter life expectancy. ${ }^{76}$

In relation to oxidative stress, it has been proposed that it is another of the most plausible mediators between adverse fetal growth and a higher risk for CVD and metabolic disease in adulthood. ${ }^{77}$

Excess ROS produced by vascular, immune, and dendritic cells and enzyme systems may account for several organ system alterations, such as endothelial dysfunction with increased vascular tone, which has been demonstrated in animal models subjected to protein restriction during gestation. $8,54,78$

The evidence indicates that maternal malnutrition, sodium overload during pregnancy, and placental dysfunction are associated with higher oxidative stress and nitric oxide-ROS imbalance in the fetal kidney, which is capable of programming renal disease and HTN in adulthood. ${ }^{54,79}$

TABLE 2. Some factors involved in early programming of $H T N^{4}$

\begin{tabular}{|c|c|c|c|c|}
\hline $\begin{array}{l}\text { Epigenetic } \\
\text { regulation }\end{array}$ & $\begin{array}{c}\text { Hormonal } \\
\text { changes }\end{array}$ & $\begin{array}{l}\text { ROS } \\
\text { changes }\end{array}$ & $\begin{array}{c}\text { Vascular/hemodynamic } \\
\text { changes }\end{array}$ & $\begin{array}{l}\text { Changes in } \\
\text { transporters }\end{array}$ \\
\hline DNA methylation & RAAS & Increase in superoxide & Microvascular attenuation & $\mathrm{Na}^{+} \mathrm{K}^{+}$-ATPase \\
\hline Histone modification & $\begin{array}{l}\text { Hypothalamic- } \\
\text { pituitary axis }\end{array}$ & $\begin{array}{c}\text { Activation of } \\
\text { NADPH-oxidase }\end{array}$ & Change in capillary density & $\mathrm{Na}^{+} \mathrm{K}^{+}$-ATPase \\
\hline Non-coding RNA & Natriuretic peptides & & & NKCC2 \\
\hline Chromatin formation & & & & $\begin{array}{c}\mathrm{Na}^{+}-\mathrm{Cl}^{-} \\
\text {cotransporter }\end{array}$ \\
\hline
\end{tabular}

HTN: hypertension; RAAS: renin-angiotensin-aldosterone system; ROS: reactive oxygen species;

$\mathrm{Na}+\mathrm{K}+$-ATPase: sodium-potassium adenosine triphosphatase; NADPH: nicotinamide adenine dinucleotide phosphate;

NKCC2: sodium-potassium-2 chloride cotransporter; $\mathrm{Na}^{+}-\mathrm{Cl}^{-}$cotransporter: sodium-chloride cotransporter.

The table columns are not related to each other. 


\section{STUDIES OF EXPERIMENTAL MODELS OF PERINATAL PROGRAMMING OF BLOOD PRESSURE}

The studies with experimental models of the mechanisms of developmental fetal programming of HTN and CVD in adulthood help to better interpret the results obtained in humans and allow to conduct long term studies. The most representative ones are the model of nutritional restriction during gestation, placental insufficiency, hypoxia, and exposure to glucocorticoids (Table 3). ${ }^{3,4,6-8,23}$

These models establish that, among cardiovascular risk factors, HTN is more frequently associated with IUGR due to nutritional imbalances. ${ }^{3,4}$

\section{PREVENTIVE MEASURES IN THE POPULATION AT RISK FOR HTN}

The current evidence suggests that several mechanisms are involved in the development of HTN programmed by an unfavorable prenatal, perinatal, and postnatal environment. ${ }^{3-5}$

Clinical prevention strategies aimed at avoiding the risk for HTN since critical development periods suggest controlling and identifying risk factors. It is important to assess the presence of a history of infection and medication, alcohol, drug or tobacco use and to perform clinical and ultrasound controls. Weight, height, BP, and metabolic status should be recorded and different dietary micronutrient or mineral intake should be monitored. $3,4,6,7,50,80,81$
And in the case of infants with a LBW, preterm birth, macrosomia, and a family history of HTN, it is necessary to carry out a clinical followup during their childhood and adolescence, with BP and glycemia controls and warranting breastfeeding and complementary feeding, implementing a healthy lifestyle and physical activity to reduce the possibility of developing obesity, metabolic syndrome, diabetes, and HTN. . $^{1-4,6-8,23,50,80,81}$

\section{CONCLUSION}

The accumulation of adverse factors during preconception, intrauterine growth and development, and in the first years of life causes epigenetic changes that favor the development of HTN and CVD in adulthood with intergenerational implications. Such adverse factors may be reversed or controlled through a primordial preventive approach and strategies aimed at improving maternal, paternal, and child health, which will allow to reduce the global burden of HTN and CVD later in life.

\section{REFERENCES}

1. Flynn JT, Kaelber DC, Baker-Smith CM, Blowey D, et al. Clinical Practice Guidelines for Screening and Management of Hight Blood Pressure in Children and Adolescents. Pediatrics. 2017;140(3):e2017904.

2. Lurbe E, Agabiti-Roseic E, Kennedy Cruickshankd J, Dominiczaket A, et al. 2016 European Society of Hypertension Guidelines for the Management of high blood pressure in children and adolescents. J Hypertens. 2016 Oct;34(10): 1887-1920.

3. Sinha MD. From Pregnancy to Childhood and Adulthood:

TABLE 3. Examples of experimental models of early programming of hypertension ${ }^{4}$

\begin{tabular}{|c|c|c|c|c|}
\hline Experimental model & Studied species & Number of nephrons & Glomerular histology & Blood pressure \\
\hline Calorie restriction & Rats, mice, Guinea pigs & Reduced & Glomerular hypertrophy & Normal or high \\
\hline Low protein diet & $\begin{array}{c}\text { Rats, mice, Guinea pigs, } \\
\text { sheep }\end{array}$ & Reduced but variable & Glomerular hypertrophy & Normal or high \\
\hline $\begin{array}{l}\text { Diet with } \\
\text { multiple deficiencies }\end{array}$ & Rats & Reduced & Glomerular hypertrophy & Normal or high \\
\hline Dexamethasone & $\begin{array}{l}\text { Rats, mice, Guinea pigs, } \\
\text { sheep }\end{array}$ & $\begin{array}{l}\text { Reduced or } \\
\text { unmodified }\end{array}$ & $\begin{array}{c}\text { Glomerular hypertrophy } \\
\text { or segmental } \\
\text { glomerulosclerosis }\end{array}$ & Normal or high \\
\hline Diabetes & Mice, rats & $\begin{array}{l}\text { Reduced or } \\
\text { unmodified }\end{array}$ & Glomerular hypertrophy & Normal or high \\
\hline $\begin{array}{l}\text { Partial uterine } \\
\text { artery ligation }\end{array}$ & Rats & Reduced & Glomerular hypertrophy & Normal or high \\
\hline
\end{tabular}


The Trajectory of Hypertension. In: Lurbe E, Whül E (eds). Hypertension in children and adolescent: New perspectives. Cham: Springer; 2019.Págs.1-16.

4. IngelfingerJR. The Contributions of Perinatal Programming to Blood Pressure Levels in Childhood and Beyon. In: Lurbe E, Whül E (eds). Hypertension in children and adolescent: New perspectives. Cham: Springer; 2019.Págs.17-30.

5. Singh RR, Denton KM, Bertram JF. Perinatal Programming of Arterial Pressure. In: Flynn JT, Ingelfinger J, Redwine K (eds). Pediatric Hypertension. $4^{\text {th }}$ ed. Cham: Springer; 2018.Pages.135-58.

6. Ingelfinger J, Nuyt AM. Impact of fetal programming, birth weight, and infant feeding on later hypertension. J Clin Hypertens (Greenwich). 2012; 14(6):365-71.

7. Ingelfinger JR, Woods LL. Perinatal programming, renal development, and adult renal function. Am J Hypertens. 2002; 15(2 Pt 2):S46 $\square$.

8. Nuyt AM. Mechanisms underlying developmental programming of elevated blood pressure and vascular dysfunction: evidence from human studies and experimental animal models. Clin Sci (Lond). 2008;114(1):117.

9. Poston L. Influence of maternal nutritional status on vascular function in the offspring. Microcirculation. 2011; 18(4):256-62.

10. Barker DJ, Osmond C. Death rates from stroke in England and Wales predicted from past maternal mortality. Br Med J (Clin Res Ed). 1987; 295(6590):83-6.

11. Barker DJ, Bull AR, Osmond C, Simmonds SJ. Fetal and placental size and risk of hypertension in adult life. BMJ. 1990; 301(6746):259-62.

12. Roseboom TJ, van der Meulen JH, Osmond C, Barker DJ, et al. Coronary heart disease after prenatal exposure to the Dutch famine, 1944-45. Heart. 2000; 84(6):595-8.

13. Stein AD, Zybert PA, van der Pal-de Bruin K, Lumey LH. Exposure to famine during gestation, size at birth, and blood pressure at age $59 \mathrm{y}$ : evidence from the Dutch famine. Eur J Epidemiol. 2006; 21(10):759-65.

14. Eriksson JG, Forsén TJ, Kajantie E, Osmond C, Barker DJ. Childhood growth and hypertension in later life. Hypertension. 2007; 49(6):1415-21.

15. de Jong F, Monuteaux MC, van Elburg RM, Gillman MW, Belfort MB.Systematic review and meta-analysis of preterm birth and later systolic blood pressure. Hypertension. 2012; 59(2):226-34.

16. Adair LS, Cole TJ. Rapid child growth raises blood pressure in adolescent boys who were thin at birth. Hypertension. 2003; 41(3):451-6.

17. Barker DJ, Osmond C, Forsén TJ, Kajantie E, Eriksson JG. Trajectories of growth among children who have coronary events as adults. N Engl J Med. 2005; 353(17):1802-9.

18. Ferraro AA, Barbieri MA, da Silva AAM, Grandi C, et al. Contributions of relative linear growth and adiposity accretion from birth to adulthood to adult hypertension. Sci Rep. 2017; 7(1):8928.

19. Parkinson JR, Hyde MJ, Gale C, Santhakumaran S, Modi N. Preterm birth and the metabolic syndrome in adult life: a systematic review and meta-analysis. Pediatrics. 2013; 131(4):e1240-63.

20. Brennan KA, Olson DM, Symonds ME. Maternal nutrient restriction alters renal development and blood pressure regulation of the offspring. Proc Nutr Soc. 2006; 65(1):11624.

21. King JC. Maternal obesity, metabolism, and pregnancy outcomes. Annu Rev Nutr. 2006; 26:271-91.
22. Chourdakis E, Fouzas S, Papadopoulou C, Oikonomou N, et al. Effect of Early-Onset Preeclampsia on Offspring's Blood Pressure during the First Month of Life. J Pediatr. 2020; 220:21-6.e1.

23. Dasinger JH, Alexander BT. Gender differences in developmental programming of cardiovascular diseases. Clin Sci (Lond). 2016; 130(5):337-48.

24. Blake KV, Gurrin LC, Evans SF, Beilin LJ, et al. Maternal cigarette smoking during pregnancy, low birth weight and subsequent blood pressure in early childhood. Early Hum Dev. 2000; 57(2):137-47.

25. Kenna K, Sozo F, De Matteo R, Hanita T, et al. Alcohol exposure during late gestation: multiple developmental outcomes in sheep. J Dev Orig Health Dis. 2012;3(4):224-36.

26. Thomal JT, Palma BD, Ponzio BF, Franco MCP, et al. Sleep restriction during pregnancy: hypertension and renal abnormalities in young offspring rats. Sleep. 2010; 33(10):1357-62.

27. McGowanPO,MatthewsSG.Prenatalstress, glucocorticoids, and developmental programming of the stress response. Endocrinology. 2018; 159(1):69-82.

28. Anwar MA, Saleh AI, Al Olabi R, Al Shehabi TS, Eid AH. Glucocorticoid-induced fetal origins of adult hypertension: association with epigenetic events. Vasc Pharmacol. 2016; 82:41-50.

29. Cottrell EC, Seckl JR. Prenatal stress, glucocorticoids and the programming of adult disease. Front Behav Neurosci. 2009; 3:19.

30. Stark MJ, Wright IM, Clifton VL. Sex-specific alterations in placental 11beta-hydroxysteroid dehydrogenase 2 activity and early postnatal clinical course following antenatal betamethasone. Am J Physiol Regul Integr Comp Physiol. 2009; 297(2):R510-4.

31. Christian P, Stewart CP. Maternal micronutrient deficiency, fetal development, and the risk of chronic disease. J Nutr. 2010; 140(3):437-45.

32. Arredondo BA, Guerrero JG, Arredondo RA. Relationship between intestinal microbiota and blood pressure. MediSan. 2019; 23(5):967-80.

33. Taal HR, Geelhoed JJ, Steegers EA, Hofman A, et al. Maternal smoking during pregnancy and kidney volume in the offspring: the Generation R Study. Pediatr Nephrol. 2011; 26(8):1275-83.

34. Gray SP, Denton KM, Cullen-McEwen L, Bertram JF, Moritz K. Prenatal exposure to alcohol reduces nephron number and raises blood pressure in progeny. J Am Soc Nephrol. 2010; 21(11):1891-902.

35. Das SK, McIntyre HD, Alati R, Al Mamun A. Maternal alcohol consumption during pregnancy and its association with offspring renal function at 30 years: observation from a birth cohort study. Nephrology (Carlton). 2019; 24(1):21-7.

36. Harskamp-van Ginkel MW, Ierodiakonou D, Margetaki K, Vafeiadi M, et al. Gestational sleep deprivation is associated with higher offspring body mass index and blood pressure. Sleep. 2020; 43(12):zsaa110.

37. Gutiérrez Arzapalo PY. Alteraciones estructurales y mecánicas vasculares asociadas a la programación fetal de lahipertensión arterial. Tesis doctoral. Madrid:Universidad Autónoma de Madrid; 2016.

38. Luyckx VA, Bertram JF, Brenner BM, Fall C, et al. Effect of fetal and child health on kidney development and longterm risk of hypertension and kidney disease. Lancet. 2013; 382(9888):273-83.

39. Brenner BM, Chertow GM. Congenital oligonephropathy and the etiology of adult hypertension and progressive 
renal injury. Am J Kidney Dis. 1994; 23(2):171 $\square 5$.

40. Mañalich R, Reyes L, Herrera M, Melendi C, Fundora I. Relationship between weight at birth and the number and size of renal glomeruli in humans: a histomorphometric study. Kidney Int. 2000; 58(2):770-3.

41. Denic A, Lieske JC, Chakkera H.A, Poggio ED, et al. The Substantial Loss of Nephrons in Healthy Human Kidneys with Aging. J Am Soc Nephrol. 2017; 28(1):313-20.

42. Cheng CJ, Lozano G, Baum M. Prenatal programming of rat cortical collecting tubule sodium transport. Am J Physiol Renal Physiol. 2012; 302(6):F674-8.

43. Wesseling S, Koeners MP, Joles JA. Salt sensitivity of blood pressure: developmental and sex-related effects. Am J Clin Nutr. 2011; 94(6 Suppl):S1928-32.

44. Alexander BT, Hendon AE, Ferril G, Dwyer TM. Renal denervation abolishes hypertension in low-birth-weight offspring from pregnant rats with reduced uterine perfusion. Hypertension. 2005; 45(2):754-8.

45. Amaral MS, Ribeiro CC, Alves MT, Ribeiro MJ, et al. Modeling Pathways From the Perinatal Factors to the Vascular Risk Phenotype at the End of the Second Decade of Life: Birth Cohort, Brazil. Hypertension. 2020; 76(2):35965.

46. Wang KC, Botting KJ, Padhee M, Zhang S, et al. Early origins of heart disease: low birth weight and the role of the insulin-like growth factor system in cardiac hypertrophy. Clin Exp Pharmacol Physiol. 2012; 39(11):958-64.

47. Zohdi V, Lim K, Pearson JT, Black MJ. Developmental programming of cardiovascular disease following intrauterine growth restriction: findings utilising a rat model of maternal protein restriction. Nutrients. 2014; 7(1):119-52.

48. Gezmish O, Tare M, Parkington HC, Morley R, et al. Maternal vitamin D deficiency leads to cardiachypertrophy in rat offspring. Reprod Sci. 2010; 17(2):168-76.

49. Morrison JL, Botting KJ, Dyer JL, Williams SJ, et al. Restriction of placental function alters heart development in the sheep fetus. Am J Physiol Regul Integr Comp Physiol. 2007; 293(1):R306-13.

50. Lewandowski AJ, Levy PT, Bates ML, McNamara PJ, et al. Impact of the vulnerable preterm hearth and circulation on adult cardiovascular disease risk. Hypertension. 2020; 76(4):1028-37.

51. Jouret B, Dulac $Y$, Bassil Eter R, Taktak A, et al. Endothelial functional and mechanical arterial properties in children born small for gestational age: comparison with obese children. Horm Res Pediatr. 2011; 76(4):240-7.

52. Martin H, Hu J, Gennser G, Norman M. Impaired endothelial function and increased carotid stiffness in 9-year-old children with low birthweight. Circulation. 2000; 102(22):2739-44.

53. Raffetto JD, KhalilRA. Matrix metalloproteinases and their inhibitors in vascular remodeling and vascular disease. Biochem Pharmacol. 2008; 75(2):346-59.

54. Guarner-Lans V, Ramírez-Higuera A, Rubio-Ruiz ME, Castrejón-Téllez V, et al. Early Programming of Adult Systemic Essential Hypertension. Int J Mol Sci. 2020; 21(4):1203.

55. Martyn CN, Greenwald SE. A hypothesis about a mechanism for the programming of blood pressure and vascular disease in early life. Clin Exp Pharmacol Physiol. 2001; 28(11):948-51.

56. Cheung YF, Wong KY, Lam BC, Tsoi NS. Relation of arterial stiffness with gestational age and birth weight. Arch Dis Child. 2004; 89(3):217-21.
57. Nilsson PM, Lurbe E, Laurent S. The early life origins of vascular ageing and cardiovascular risk: the EVA syndrome. J Hypertens. 2008; 26(6):1049-57.

58. Grassi G, Mark A, Esler M. The sympathetic nervous system alterations in human hypertension. Circ Res. 2015; 116(6):976-90.

59. Wyss JM. The role of the sympathetic nervous system in hypertension. Curr Opin Nephrol Hypertens. 1993; 2(2):265-73.

60. Norlander AE, Madhur MS, HarrisonDG. Theimmunology of hypertension. J Exp Med. 2018; 215(1):21-33.

61. Su Y, Bi J, Pulgar VM, Figueroa J, et al. Antenatal glucocorticoid treatment alters $\mathrm{Na}+$ uptake in renal proximal tubule cells from adult offspring in a sex-specific manner. Am J Physiol Renal Physiol. 2015; 308(11):F1268-75.

62. Tain YL, Lin YJ, Sheen JM, Yu HR, et al. High Fat Diets SexSpecifically Affect the Renal Transcriptome and Program Obesity, Kidney Injury, and Hypertension in the Offspring. Nutrients. 2017; 9(4):357.

63. Woods LL, Ingelfinger JR, Nyengaard JR, Rasch R. Maternal protein restriction suppresses the newborn reninangiotensin system and programs adult hypertension in rats. Pediatr Res. 2001; 49(4):460-7.

64. Wu L, Shi A, Zhu D, Bo L, et al. High sucrose intake during gestation increases angiotensin II type 1 receptor-mediated vascular contractility associated with epigenetic alterations in aged offspring rats. Peptides. 2016; 86:133-44.

65. Moritz KM, CuffeJS, Wilson LB, Dickinson H, et al. Review: sex specific programming: a critical role for the renal reninangiotensin system. Placenta. 2010; 31 (Suppl):S40-6.

66. Liang M. Epigenetic Mechanisms and Hypertension. Hypertension. 2018; 72(6):1244-54.

67. Tollefsbol TO. Epigenetics: The New Science of Genetics. In: Tollefsbol TO (ed). Handbook of Epigenetics: The New Molecular and Medical Genetics. Amsterdam: Academic Press; 2011.P.1-6.

68. Stoll S, Wang Ch, Qiu H. DNA Methylation and Histone Modification in Hypertension. Int J Mol Sci. 2018;19(4):1174.

69. Wang J, Gong L, Tan Y, Hui R, Wang Y. Hypertensive epigenetics: from DNA methylation to microRNAs. J Hum Hypertens. 2015; 29(10):575-82.

70. Mendizábal B, Urbina E, Becker R, Daniels SR, et al. SHIPAHOY (Study of High Blood Pressure in Pediatrics: Adult Hypertension Onset in Youth): rationale, design, and methods. Hypertension. 2018; 72(3):625-31.

71. Heijmans BT, Tobi EW, Stein AD, Putter H, et al. Persistent epigenetic differences associated with prenatal exposure to famine in humans. Proc Natl Acad Sci U S A. 2008; 105(44):17046-9.

72. Tobi EW, Lumey LH, Talens RP, Kremer D, et al. DNA methylation differences after exposure to prenatal famine are common and timing- and sex-specific. Hum Mol Genet. 2009; 18(21):4046-53.

73. Sinclair KD, Allegrucci C, Singh R, Gardner DS, et al. DNA methylation, insulin resistance, and blood pressure in offspring determined by maternal periconceptional B vitamin and methionine status. Proc Natl Acad Sci U S A. 2007; 104(49):19351-6.

74. Ramírez R. Programación fetal de la hipertensión arterial del adulto: mecanismos celulares y moleculares. Rev Colomb Cardiol. 2013; 20(1):23-32.

75. Bygren LO, Kaati G, Edvinsson S. Longevity determined by paternal ancestors' nutrition during their slow growth period. Acta Biotheor. 2001; 49(1):53-9.

76. Hallows SE, Regnault TR, Betts DH. The long and short of it: the role of telomeres in fetal origins of adult disease. 
J Pregnancy. 2012; 2012:638476.

77. Thompson LP, Al-Hasan Y. Impact of oxidative stress in fetal programming. J Pregnancy. 2012; 2012:582748.

78. Franco MC, Akamine EH, Rebouças N, Carvalho MH, et al. Long-term effects of intrauterine malnutrition on vascular function in female offspring: implications of oxidative stress. Life Sci. 2007; 80(8):709-15.

79. Ávila JG, Echeverri I, de Plata CA, Castillo A. Impact of oxidative stress during pregnancy on fetal epigenetic patterns and early origin of vascular diseases. Nutr Rev. 2015; 73(1):12-21.

80. Falkner B, Lurbe E. Primordial Prevention of High Blood Pressure in Childhood: an opportunity not to be missed. Hypertension. 2020; 75(5):1142-50.

81. Luyckx VA, Perico N, Somaschini M, ManfellottoD, et al. A developmental approach to the prevention of hypertension and kidney disease: a report from the Low Birth Weight and Nephron Number Working Group. Lancet. 2017; 390(10092):424-8. 